\title{
Sport Science: Progress, Hubris, and Humility
}

Sport science can mean a lot of different things. At one level, it can be the collation and transmission of scientific findings to coaches and athletes. At another, it can be the evaluation of athletes in the laboratory, intended to give the coach a venue free view of the current status and progress of the athlete toward training targets. At yet another, it can be the testing of hypotheses about the likely effects of changes in training program design, equipment modifications, or ergogenic aids, which may aid the coach in preparing athletes. Viewed from a longer perspective, it should be a lesson to sport scientists that they are (1) at best helpers to coaches, who understand their sport at a depth that is not attainable to most sport scientists, (2) subject to comparatively rapidly changing information about what data are important and how data should be interpreted, and (3) lessons in humility and cautions against the hubris that they "have the answers." In essence, sport scientists should always remember that they are about as important as a good video camera, which helps the coach "see" their athlete better.

There is always the risk-since we have a jargon about physiology and biomechanics, and have the imprimatur of scientists who are "seeking truth," quite different jargon, perhaps with simpler and more descriptive language - that we think that coaches as less schooled and understand things less profoundly. Traditionally, coaches do have less formal education and often speak in a simple, colorful, and very sport-specific jargon. Although it is becoming less common, many coaches are former elite athletes without formal academic training. So, it is easy to think of them as unschooled. But, as Stephen Seiler pointed out in a lecture some years ago, the scientific understanding of training is grounded on the 8- to 20-week randomized controlled trial, which is so much shorter than the yearly or often quadrennialbased training plans of coaches that the scientists do not really have an appreciation of the effects of long-term periodization and thus cannot really understand the important elements of the training response. The years of experience "in the field" have equipped most serious coaches with a breadth and depth of knowledge that simply is not attainable for those operating in the intentionally narrow world of experimental science.

Science is a "way of knowing," comparable in some senses to the knowledge imparted by grandparents or by religious traditions. Uniquely, science is self-correcting, in that we recognize that "things that we know with certainty" will be out of date in 25 years and more likely just completely wrong. Even the scientific anchors on which we base our understanding will change. At a certain point in my career, the maximal oxygen uptake $\left(\mathrm{VO}_{2} \max \right)$ was everything. ${ }^{2}$ Athletes with big values for $\mathrm{VO}_{2} \max$ were destined for success; athletes with lower values were supposedly doomed to be second-tier performers. ${ }^{3}$ Someone forgot to tell that to Peter Snell and Frank Shorter, dominant athletes in their day, who only had $\mathrm{VO}_{2}$ max values in the low $70 \mathrm{~mL} / \mathrm{kg}$ range. ${ }^{4,5} \mathrm{I}$ also recall, during my postdoctoral period at Ball State University, meeting Ed Coyle, who was an MS student at the same time. I was confused when Ed told me that he had a $\mathrm{VO}_{2} \max >80 \mathrm{~mL} / \mathrm{kg}$ but had only run a 1-mile race in the range of 4:10. Clearly, $\mathrm{VO}_{2} \max$, while important, was not the only important thing. In concert with the concept of a "big motor," the classic papers by Joyner ${ }^{6}$ and di Prampero ${ }^{7}$ on the determinants of performance reinforced the importance of $\mathrm{VO}_{2} \max$ as a critical parameter for sports performance. If $\mathrm{VO}_{2}$ max was not absolutely critical, perhaps something to do with lactate accumulation during exercise was the more important player ${ }^{8-10}$ Indeed, I can recall testing athletes, developing a "lactate profile," and telling them that their "ideal" training intensity was the power output or heart rate (HR) equivalent to a blood lactate concentration of $4 \mathrm{mmol} / \mathrm{L}$. That worked fine, until Seiler ${ }^{11}$ and Esteve-Lanao et al ${ }^{12,13}$ made the simple observation that this seems to be a training intensity that athletes use very selectively, usually only $10 \%$ to $15 \%$ of training volume. If not $\mathrm{VO}_{2} \mathrm{max}$, or lactate threshold or the economy of running, ${ }^{14-16}$ surely something that scientists could measure must provide the definitive answer that allows them to understand elite sport performance and give us the ability to tell coaches what everything really means. The candidate emerged in muscle-fiber composition. Surely, athletes who were more slow twitch or more fast twitch or who had higher respiratory enzymes in their muscle fibers, should have a competitive advantage. ${ }^{3,17-19}$ Although all of these laboratorybased measures were somewhat successful in terms of explaining sporting success, we really have failed to hit on a single measure that will let the scientists tell the coach what is really important.

Well, if physiological parameters are not the scientific answer that makes sport science valuable, maybe knowledge of the training response is. Coaches had long ago discovered for themselves the value of more training and harder training. Interval training had been created in the late 1930s with some very specific (run to $\mathrm{HR}=180 /$ recover to $\mathrm{HR}=120$ ) guidelines that were supposedly scientifically based, although, despite extensive correspondence, I cannot find anyone who knows why those particular values for HR were selected. Bannister's group had evolved the concept of the Training Impulse in the 1990s, allowing integration of training intensity and duration. ${ }^{20}$ Seiler $^{11}$ and Esteve-Lanao et $\mathrm{al}^{13}$ came up with the concept of training-intensity distribution using the conceptual format of Bannister. We came up with the session RPE (rating of perceived exertion) in the late 1990s, designed to simplify and augment the concept of training-intensity distribution by accounting for hard days and easy days ${ }^{21-24}$ and training periodization, ${ }^{25}$ which are known to augment the training response. ${ }^{26,27}$ Mujika and Padilla ${ }^{28}$ and Hickson et $\mathrm{al}^{29}$ have documented the effect of taper on the training response, but we have yet to come up with a unified field theory that is of practical benefit to coaches trying to better understand the training response in their athletes. Important recent progress has been made in terms of differentiating the "internal" and "external" training loads, ${ }^{30}$ but the fact remains that our science is still less than ideally practical.

There has been progress with integrating the knowledge base of sport science into practical solutions that can be useful to coaches and athletes. In the early 1970s, the English marathon runner Ron Hill, who was trained as a PhD textile chemist, delved into some of the early studies of muscle glycogen storage and depletion from Sweden ${ }^{31,32}$ and came up with the basic outline for carbohydrate loading that was used by athletes for many years. ${ }^{33}$ 
Later work by Sherman et $\mathrm{al}^{34}$ demonstrated that the prolonged period of glycogen depletion could be shortened without loss of effect. van Ingen Schenau et $\mathrm{al}^{35}$ and de Koning et $\mathrm{al}^{36}{ }^{36}$ working from first principles of locomotion, developed the klapskate, which revolutionized speed-skating performances within a single year. My own best contribution was to take published results from Ivy et $\mathrm{al}^{37}$ about the rapidity of muscle glycogen replacement after exercise to guide speed-skating coaches regarding how they should refuel their athletes between competitive events. So, translation of basic scientific understanding into strategies that are of practical use is possible, but it is done far too little.

So, sport science is important. But, its importance is probably less in the domain of evaluating athletes, where coaches already have access to competitions and standard training sessions. When we have tried to tie our recommendations to specific laboratory parameters, we have more often demonstrated our ignorance, indeed our hubris, than been really helpful. There is potential for an integrated understanding of the training response, but limited data and narrow ways of looking at data have prevented us from developing the unified field theory ${ }^{38}$ that would be of considerable use. Systematic review of the literature about ergogenic aids and/or equipment modifications holds promise but is too seldom accomplished. In any case, as practicing sport scientists, we are obligated to continually reexamine what our best role is in support of coaches and athletes.

Carl Foster, IJSPP Editor Emeritus, University of Wisconsin-La Crosse

\section{References}

1. Foster C, Anholm JD, Best T, et al. Scientific discovery and its role in sports science. Kinesiology. 2016;48(2):274-284.

2. Saltin B, Astrand PO. Maximal oxygen uptake in athletes. J Appl Physiol. 1967;23:353-358. PubMed ID: 6047957 doi:10.1152/jappl. 1967.23.3.353

3. Foster C, Costill DL, Daniels JT, Fink WJ. Skeletal muscle enzyme activity, fiber composition and $\mathrm{VO}_{2} \mathrm{max}$ in relation to distance running performance. Eur J Appl Physiol. 1978;39:73-80. doi:10. 1007/BF00421711

4. Pollock ML. Submaximal and maximal working capacity of elite distance runners; part 1: cardiorespiratory aspects. Ann N Y Acad Sci. 1977;301:310-322. PubMed ID: 270924 doi:10.1111/j.1749-6632. 1977.tb38209.x

5. Carter JE, Kasch FW, Boyer JL, Phillips WH, Ross WD, Sucec A. Structural and functional assessments on a champion runner-Peter Snell. Res Q Exerc Sport. 1967;38:355-365.

6. Joyner MJ. Optimal marathon performance on the basis of physiological factors. J Appl Physiol. 1991;70:683-687. PubMed ID: 2022559 doi:10.1152/jappl.1991.70.2.683

7. di Prampero PE. Factors limiting maximal performance in humans. Eur J Appl Physiol. 2003;90:420-429. PubMed ID: 12910345 doi: 10.1007/s00421-003-0926-z

8. Farrell PA, Wilmore JH, Coyle EF, Billing JE, Costill DL. Plasma lactate accumulation and distance running performance. Med Sci Sports. 1979;11:338-344. PubMed ID: 8231751

9. Sjodin B, Svendenhag J. Applied physiology of marathon running. Sports Med. 1985;2:83-99. PubMed ID: 3890068 doi:10.2165/ 00007256-198502020-00002

10. Hartmann U, Mader A, Petersmann G, Grabow V, Hollmann W. Verhalten von herzfrequenz und laktat wahrend ruderspezifischer trainingsmethoden. Dtsch Z Sportmed. 1989;40:200-212.
11. Seiler $\mathrm{S}$. What is the best practice for training intensity and duration distribution. Int J Sports Physiol Perf. 2010;5:276-291. doi:10.1123/ ijspp.5.3.276

12. Esteve-Lanao J, San Juan AF, Earnest C, Foster C, Lucia A. How do endurance runners actually train? Relationships with competition performance. Med Sci Sports Exerc. 2005;37:496-504. doi:10. 1249/01.MSS.0000155393.78744.86

13. Esteve-Lanao J, Foster C, Seiler S, Lucia A. Impact of the training intensity distribution on performance in endurance athletes. J Strength Cond Res. 2007;21:943-949.

14. Daniels J, Krahenbuhl G, Foster C, Gilbert J, Daniels S. Aerobic responses of female distance runners to submaximal and maximal exercise. Ann N Y Acad Sci. 1977;301:726-733. PubMed ID: 270948 doi:10.1111/j.1749-6632.1977.tb38242.x

15. Lucia A, Esteve-Lano J, Olivan J, et al. Physiological characteristics of the best Eritrean runners-exceptional running economy. Appl Physiol Nutr Metabol. 2006;31:530-540. doi:10.1139/ h06-029

16. Foster C, Lucia A. Running economy: the forgotten factor in elite performance. Sports Med. 2007;37:316-319. PubMed ID: 17465597 doi:10.2165/00007256-200737040-00011

17. Costill DL, Fink WJ, Pollock ML. Muscle fiber composition and enzyme activities of elite distance runners. Med Sci Sports. 1976; 8:96-100. PubMed ID: 957938

18. Sjodin B, Jansson E. Muscle fiber type changes with sprint training: effect of training pattern. Acta Physiol Scand. 1993;149:245-246. doi:10.1111/j.1748-1716.1993.tb09618.x

19. Coyle EF, Sidossis LS, Horowitz JF, Beltz JD. Cycling efficiency is related to the percentage of type I muscle fibers. Med Sci Sports Exerc. 1992;24:782-788. PubMed ID: 1501563

20. Bannister EW, Carter JB, Zarkadas PC. Training theory and taper: validation in triathlon athletes. Eur J Appl Physiol. 79;1999:182-191. doi: $10.1007 / \mathrm{s} 004210050493$

21. Foster C, Hector LL, Welsh R, Schrager M, Green MA, Snyder AC. Effects of specific vs cross training on running performance. Eur $J$ Appl Physiol. 1995;70:367-372. doi:10.1007/BF00865035

22. Foster C, Florhaug JA, Franklin J, et al. A new approach to monitoring exercise training. J Strength Cond Res. 2001;15:109-115. PubMed ID: 11708692

23. Foster C. Monitoring training in athletes with reference to overtraining syndrome. Med Sci Sports Exerc. 1998;30:1164-1168. PubMed ID: 9662690 doi:10.1097/00005768-199807000-00023

24. Foster C, Rodriguez-Marroyo J, de Koning JJ. Monitoring training loads: the past, the present and the future. Int J Sports Physiol Perf. 2017;12:S22-S28. doi:10.1123/IJSPP.2016-0388

25. Sylta O, Tonnessen E, Hammarstrom D, et al. The effect of different high-intensity periodization models on endurance adaptations. Med Sci Sports Exerc. 2016;48:2165-2174. PubMed ID: 27300278 doi: 10.1249/MSS.0000000000001007

26. Hansen AK, Fischer CP, Plomgaard P, et al. Skeletal muscle adaptation: training twice every second day vs training once a day. $J \mathrm{Appl}$ Physiol. 2005;98:93-99. PubMed ID: 15361516 doi:10.1152/ japplphysiol.00163.2004

27. Yeo WK, Paton CD, Garnham AP, Burke LM, Carey AL, Hawley JA. Skeletal muscle adaptation and performance responses to once a day versus twice every second day endurance training regimes. $J$ Appl Physiol. 2008;105:1462-1470. PubMed ID: 18772325 doi:10.1152/ japplphysiol.90882.2008

28. Mujika I, Padilla S. Detraining: loss of training-induced physiological and performance adaptations. Part I: short term insufficient training stimulus. Sports Med. 2000;30:79-87. PubMed ID: 10966148 doi: $10.2165 / 00007256-200030020-00002$ 
29. Hickson RC, Foster C, Pollock ML, Galassi TM, Rich S. Reduced training intensities and loss of aerobic power, endurance and cardiac growth. J Appl Physiol. 1985;58:492-499. PubMed ID: 3156841 doi:10.1152/jappl.1985.58.2.492

30. Impellizzeri FM, Marcora SM, Coutts AJ. Internal and external training load: 15 years on. Int J Sports Physiol Perf. 2019; 14(2). doi:10.1123/ijspp.2018-0935

31. Hermansen L, Hultman E, Saltin B. Muscle glycogen during prolonged severe exercise. Acta Physiol Scand. 1967;71:129-139. PubMed ID: 5584522 doi:10.1111/j.1748-1716.1967.tb03719.x

32. Bergstrom J, Hermansen L, Hultman E. Diet, muscle glycogen and performance. Acta Physiol Scand. 1967;71:140-150. PubMed ID: 5584523 doi:10.1111/j.1748-1716.1967.tb03720.x

33. Karlsson J, Saltin B. Diet, muscle glycogen and endurance performance. J Appl Physiol. 1971;31:203-206. PubMed ID: 5558241 doi:10.1152/jappl.1971.31.2.203

34. Sherman WM, Costill DL, Fink WJ, Miller JM. Effect of exercise-diet manipulation on muscle glycogen and its subsequent utilization during performance. Int J Sports Med. 1981;2:114-118. PubMed ID: 7333741 doi:10.1055/s-2008-1034594

35. van Ingen Schenau GJ, de Groot G, Scheurs AW, Meester H, de Koning JJ. A new skate allowing powerful plantar flexion improves performance. Med Sci Sports Exerc. 1996;28:531-535. PubMed ID: 8778561 doi:10.1097/00005768-199604000-00020

36. de Koning JJ, Houdijk H, de Groot G, Bobbert MF. From biomechanical theory to application in top sports: the Klapskate story. J Biomech. 2000;33:1225-1229. PubMed ID: 10899331 doi:10. 1016/S0021-9290(00)00063-4

37. Ivy JL, Katz AC, Cutler CC, Sherman WM, Coyle EF. Muscle glycogen synthesis after exercise: effect of time of carbohydrate ingestion. J Appl Physiol. 1988;64:1480-1485. PubMed ID: 3132449 doi:10.1152/jappl.1988.64.4.1480

38. Foster C. In quest of the unified field theory of exercise training. Int J Sports Physiol Perf. 2015;10:1-2. doi:10.1123/ijspp.20140542 